\title{
Primeiro Transplante de Fígado em Ribeirão Preto
}

O dia 2 de maio de 2001 será lembrado não só por ter sido o dia da realização do $1^{o}$ transplante de fígado no HC-FMRP-USP, mas, também e sobretudo, por ter sido o dia da consolidação do $3^{\circ}$ Centro de Transplante Hepático do interior do Estado de São Paulo.

O transplante de fígado, mais do que uma necessidade assistencial, numa instituiçào envolvida com atendimento de ponta, é um gerador inesgotável de pesquisa de alto nível numa instituição comprometida com o ensino e com a investigação científica.

$\mathrm{N}$ o último fascículo da Revista Medicina do ano passado, junto com a Profa. Ana Martinelli, escrevi o editorial, comentando alguns fatos que culminaram com a criação do Grupo Integrado de Transplante de Fígado em nossa instituição, o Hospital das Clínicas da FMRP-USP(1). No último parágrafo, enfatizei que toda a infra-estrutura encontrava-se pronta, e que dois mil e um despontava, trazendo o novo século e a certeza da ousadia precisa e calculada do primeiro transplante, o marco esperado de uma longa história. $E$ assim ocorreu, e quis o destino que todo o preparativo da cirurgia começasse no dia anterior, primeiro de maio, Dia do Trabalho, quando o fígado do doador foi explantado, na Unidade de Emergência, para que, na madrugada do dia 2 da maio, na sala 6 do Centro Cirúrgico do HC Campus se realizasse o implante no paciente receptor. Para toda a equipe envolvida, o primeiro transplante foi o coroamento de extenuante trabalho desenvolvido ao longo de anos, que culminou com o sucesso da operação e, dias depois, com a alta hospitalar.
O transplante de fígado no HC-FMRP-USP era esperado já com ansiedade não só pela comunidade local como, também, pela nacional; mais do que uma obrigação acadêmica, era uma necessidade social, pois dele dependia o destino de pacientes que aguardavam na fila de espera por um órgão que lhes possibilitasse a continuidade da vida. Como cirurgião e como professor desta instituição, sem afastar-me das enfermarias e do centro cirúrgico, dediquei-me, por quase dez anos, à preparação das bases experimentais, bioquímicas e à formação de recursos humanos para a realização do transplante clínico de fígado. Isso mereceu ,ao longo dos anos, o reconhecimento da FAPESP(2) com a aprovação de vários projetos, o que significou a injeção de recursos financeiros para a compra de equipamentos, muitos deles utilizados no primeiro transplante de fígado, no último dia dois de maio. A partir de 1992,quando iniciei, neste hospital, HC-FMRP-USP, o programa clínico de hepatectomias para tratamento de tumores de fígado, fui convivendo com a cirurgia hepática em enfermos com doenças do fígado, sem nunca 
afastar-me da cirurgia experimental. A convicção de que a investigação científica e a clínica cirúrgica devem estar interligadas, para o sucesso de uma e de outra, norteou sempre minha conduta universitária. O dia do transplante do fígado e, sobretudo, o dia em que assinei a alta hospitalar do enfermo transplantado e pude vê-lo, em companhia da esposa e da mãe, deixar o hospital para iniciar vida nova, foram, profissionalmente, os dias mais felizes de minha vida, pois, o sonho se materializava e uma cirurgia de alta complexidade chegara ao fim, mostrando que todo o trabalho anterior não tinha sido em vão.

Tenho a convicção de que o transplante de fígado será um programa que se solidificará nesta instituição, comprovando um fenômeno, ,já observado em todos os centros transplantadores do mundo, a melhora, pela tecnologia que incorpora e transfere dentro da instituição, da qualidade da assistência, do ensino e da pesquisa, Nas página 194-199, do presente fascículo está publicado o relato detalhado do $1^{\circ}$ caso de tranplante de fígado(3), e ali estão relacionados os membros da equipe que participaram do procedimento, desde o momento da notificação do doador, na Unidade de Terapia Intensiva da Unidade de Emergência, na tarde do dia 10., até o final da tarde daquele ensolarado 2 de maio de 2001. O terceiro Centro de Transplante de Fígado do Estado de São Paulo estava definitivamente consolidado. A história havia apenas começado.

1- CASTRO E SILVA JR O \& MARTINELLI ALC. Transplante de fígado. Uma realidade no Hospital das Clínicas da FMRP-USP para o ano de 2001. Medicina, Ribeirão Preto, 33: 373- 376, 2000

2- CASTRO E SILVA JR O. Regeneração Hepática e Transplante de Fígado. Projeto Temático, FAPESP- Processo nํ 96/ 01560-2

3- FRANÇA, AVC MARTINELLI, A LC SANKANRANKUTTY, AK, RIZZOCC, CASTRO E SILVA JUNIOR,O E GRUPO INTEGRADO DE TRANSPLANTE DE FÍGADO do HCFMRP-USP. Transplante de fígado. Relato do primeiro caso realizado no Hospital das Clínicas da Faculdade de Medicina de Ribeirão Preto da Universidade de São Paulo. Medicina, Ribeirão Preto 34: 194-199, 2001.

Prof.Dr. Orlando de Castro e Silva Jr Docente do Departamento de Cirurgia e Anatomia Coordenador do Grupo Integrado de

Transplante de Figado do HC-FMRP-USP 